\title{
Emergency treatment of food anaphylaxis: a report of 152 cases registered by the Allergy Vigilance Network
}

\author{
A Moneret-Vautrin \\ From Food Allergy and Anaphylaxis Meeting (FAAM 2013) \\ Nice, France. 7-9 February 2013
}

\section{Background}

International guidelines are in place for the management of severe food anaphylaxis. Their implementation in emergency services is examined to identify the points needing improvement.

\section{Methods}

One hundred and fifty-two cases of severe anaphylaxis were reported to the Allergy Vigilance Network in France and Belgium in 2011. Information was recorded on a standardised form. A thorough analysis was then undertaken.

\section{Results}

78 paediatric and 74 adult cases were reported. Two deaths occurred. Personnel and emergency centres involved in the management were known in 147 cases, and treatment in 136 cases. First-aid was provided at home by patients themselves on 43 occasions or by the family physician 12 times. 49 called for an ambulance. 89 required hospitalisation in an Emergency Department. Epinephrine auto-injectors were used by 4 patients only. Medicalized ambulances treated 23 patients, and used epinephrine in 11/23 cases. Emergency departments treated 58 patients and used epinephrine in 19 cases. When epinephrine had been injected before arriving at the ED, no further injection in hospital was necessary. In total, epinephrine was given to 37 patients (27.2\%). The observation period was much shorter than recommended in the Directives. Patients were discharged without care summaries. Allergists implemented school management plans for all children. 68 to $80 \%$ of patients were prescribed self-injectable epinephrine.

\section{Conclusion}

Personal care plans including patient education on the use of epinephrine should be more widely used. The frequent prescription of self-injectable epinephrine to the patients is almost at no use. As patients fail to use them when necessary, paramedics should be equipped with auto-injectors and trained to identify severe symptoms. We recommend improved coordination between emergency doctors, paediatricians and allergists.

\section{Disclosure of interest}

None declared.

Published: 25 July 2013

Table 1 Clinical features of severe food anaphylaxis treated by epinephrine.

\begin{tabular}{ccccc}
\hline Clinical features & $\begin{array}{c}\text { \% paediatric population } \\
\mathbf{7 8} \text { cases }\end{array}$ & $\begin{array}{c}\text { \% adult population } \\
\mathbf{7 4} \text { cases }\end{array}$ & $\begin{array}{c}\text { \% total population } \\
\mathbf{1 5 2} \text { cases }\end{array}$ & $\begin{array}{c}\text { \% treatment by epinephrine } \\
\mathbf{3 7} \text { cases }\end{array}$ \\
\hline Anaphylactic shock & 8.9 & 24.2 & 16.4 & 54.2 \\
Systemic reaction & 66,6 & 51.3 & 59.2 & 16.3 \\
Acute asthma & 2.6 & 5.4 & 3.9 & 66.7 \\
Laryngeal angioedema & 11.5 & 12.2 & 11.8 & 16.7 \\
\hline
\end{tabular}

Nancy University, Vandoeuvre les Nancy, France 


\section{References}

1. Moneret-Vautrin DA, Morisset M, et al: Allergy 2005, 60:443-51.

2. Muraro A, Roberts G, et al: Allergy 2007, 62(8):857-71.

3. Worm M, Timmermans F, et al: Allergy 2010, 65:671-80.

4. Capps JA, Sharmab V, et al: Resuscitation 2010, 81:653-7.

5. Arroabarren E, Lasa EN, et al: Pediatr Allergy Immunol 2011, 22:708-714.

doi:10.1186/2045-7022-3-S3-01

Cite this article as: Moneret-Vautrin: Emergency treatment of food anaphylaxis: a report of 152 cases registered by the Allergy Vigilance Network. Clinical and Translational Allergy 2013 3(Suppl 3):01.

Submit your next manuscript to BioMed Central and take full advantage of:

- Convenient online submission

- Thorough peer review

- No space constraints or color figure charges

- Immediate publication on acceptance

- Inclusion in PubMed, CAS, Scopus and Google Scholar

- Research which is freely available for redistribution

Submit your manuscript at www.biomedcentral.com/submit
() BioMed Central 